\title{
Spatially blind policies? Analysing agglomeration economies and European Investment Bank funding in European Neighbouring Countries
}

\author{
David Castells-Quintana and Vicente Royuela
}

\begin{abstract}
:
Agglomeration economies are a key factor of modern economic development, although to take full advantage of agglomeration economies that come with urban concentration, infrastructure plays a key role. Policies promoting development need to take into account the fact that globalisation has made space more rather than less important. For a long time development policies have focused on the provision of infrastructure. In this work we analyse: first how urban concentration and infrastructure interact with each other for encouraging economic growth; and second if policies promoting infrastructure have considered the spatial distribution of economic activity. As a case study we focus on the European Investment Bank (EIB) funding and lending instruments for financing infrastructures, for both the European Union and the EU neighbourhood. We perform panel data analysis considering different measures of infrastructure (as the provision of basic urban services, transport, and communications) and we also analyse the EIB projects. Our results suggest a relevant role of connectivity infrastructure (i.e. transport and communications) for agglomeration benefits to take place in European Neighbouring Policy countries. Our results also suggest that policies promoting development are more country specific for these neighbouring countries than for the EU countries: while for the EU spatial issues seem to matter, even after controlling for time, sectoral, and country-specific factors, this is not the case for EU neighbouring countries.
\end{abstract}

JEL codes: O18, R41, R42, R53, H54

Keywords: spatially blind policies, agglomeration economies, economic growth, infrastructures, EU, ENP, EIB

Acknowledgments The research leading to these results has received funding from the European Community's Seventh Framework Programme (FP7/2010-2.2-1) under Grant Agreement No. 266834. We also acknowledge the support of ECO2013-41022R.

David Castells-Quintana,

Department of Applied Economics. Universidad Autònoma de Barcelona.

AQR-IREA Research Group. Universidad de Barcelona

dcastells@ub.edu

Vicente Royuela,

AQR-IREA Research Group. Universidad de Barcelona

vroyuela@ub.edu 


\section{Spatially blind policies? Analysing agglomeration economies and European Investment Bank funding in European Neighbouring Countries}

\section{Introduction}

Spatially blind policies are considered to be those that are universal in their coverage such as those associated with trade, regulation of land use or labour. These policies, though, are not necessarily blind in effect, as Hewings (2014) shows. On the contrary, regional development policies are usually justified as a way to correct market failures, many times assuming that the benefits of these policies are going to take place in regions where investments are made. Among the latter type of policies, investment in infrastructures has received a large attention of academics for decades.

Infrastructure is a heterogeneous concept that includes physical structures of various types, such as "economic infrastructure" (i.e., network utilities) and "social infrastructure" (i.e., schools and hospitals). Similarly, infrastructures can be "national" (such as roads and telephone networks) and "urban" (such as sanitation facilities). Infrastructure affects economic development in two ways: (i) by the importance of the sector itself on GDP and as an input of other sectors; and (ii) by improving overall productivity. As Kessides (1996) highlights, infrastructure promotes development not only by increasing productivity but also by providing amenities that enhance the quality of life. Infrastructure also contributes to growth by enhancing structural change, including favouring economic diversification and technological innovation, and by changing the structure of production and consumption.

According to Hakfoort (1996), most studies report a significant positive effect of infrastructure on development, although the recent literature tends to report smaller effects than what was reported earlier, as a result of asset-quality issues, non-linearities and, not less importantly, the need of a spare capacity as a necessary condition for a properly functioning system. Hakfoort highlights the lack of empirical evidence paying attention on how congestion of "impure public goods" (as transportation infrastructure) leads to a suboptimal growth path, while Newbery (2012) remembers that to the extent that suboptimal infrastructure investment constrains other investment, it constrains growth. ${ }^{1}$ As Estache (2010) remembers, the opportunity cost of infrastructure investment gaps in terms of growth and productivity is the more important the poorer is the country. Consequently, it is needed to consider different levels of development when analysing this relationship.

Among all infrastructures, transport is the single largest sector by investment, accounting for more than half of total investment, followed by utilities (i.e. energy, water, and waste and sewage) (Wagenvoort et al., 2010). The provision of these different types of infrastructure has an impact on the spatial distribution of population and economic activity. Within the context of the New Economic Geography models (Fujita et al. 1999),

\footnotetext{
${ }^{1}$ See Romp and Haan (2007) and Straub (2008) for a review of the relevant empirical literature.
} 
improving connectivity between cities can result in spatial agglomeration. And, as Anderson and Lakshmanan (2007) note, agglomeration economies are the most important spatial process promoting productivity growth. Hence, agglomeration economies taking place in urban areas represent one underlying mechanism through which infrastructure can potentially enhance productivity.

Urban agglomeration, in particular the degree of urban concentration, has been found to strongly affect economic growth (Henderson 2003; Brulhart and Sbergami 2009; Castells-Quintana and Royuela 2014). The 2009 World Development Report (WDR) stressed that "economic development is seldom balanced... efforts to spread it prematurely will jeopardize progress" (World Bank 2009, p. 6). This leads to increasing income disparities across regions, especially in developing countries. However, the WDR also points out that "the question is whether growing concentrations of humanity will increase prosperity, or produce congestion and squalor” (World Bank 2009, p.3).

In the urban economics literature the nature of the national urban system and the interactions between cities (Duranton and Puga 2000), as well as the functional characteristics of cities themselves (Camagni et al. 2013; Capello and Camagni 2000; Royuela and Suriñach 2005) have been suggested as further determinants of the benefits and costs from agglomeration. By improving the connectivity between cities or by lowering congestion and dis-amenities within them, infrastructure developments are expected to affect the benefits from urban concentration (see also Bertinelli and Black 2004 and Henderson 2005). ${ }^{2}$ In this line, we assume that the way that countries can exploit the full benefits of agglomeration economies depends on the quantity and type of infrastructures provision. ${ }^{3}$ Thus, we can expect that the national rate of economic growth will depend not only on the process of urban concentration, but also on its interaction with the development of infrastructure (either of all types or specific - i.e., connectivity or urban).

In policy terms, the relevant question concerns whether public funding associated with the provision of infrastructures is explicitly considering such relationship. ${ }^{4}$ In the recent years a public debate is devoted to the "spatial-footprint" of public policies. Barca et al.

\footnotetext{
${ }^{2}$ Henderson (2000) finds a significant role of road density in defining urban concentration and the benefits and costs associated with it. Capello and Camagni (2000) and Royuela et al. (2010) consider telephone lines as a proxy for network integration of cities.

${ }^{3}$ Gifford (1996) emphasises the complexity behind sound infrastructure planning and development. Given increasing returns (due to, among other things, coordination effects, large setup costs, and learning by doing) there is a potential "lock in" and path dependence, which can lead to lower level of productivity and welfare when new and better alternative systems become available but are difficult to adopt.

${ }^{4}$ Public policies are intimately linked with the provision of public goods. Governments decide on the systems and the frameworks from a social optimisation perspective, and also control the planning and development of these systems. Infrastructures are long-lived assets with high sunk costs and low marginal costs. Private investors only operate if they enjoy a sufficiently large cash flow, representing average rather than marginal cost (Wagenvoort et al., 2010). As stressed by Lundqvist and Mattsson (2002), integrated approaches are increasingly demanded for decision schemes capable of providing information on long-run effects of infrastructure, in line with a strong policy sensitivity that orientates national infrastructure systems.
} 
(2012) explain how globalization has made localities and their interaction more relevant for economic growth and prosperity, where space has become more rather than less relevant. The 2009 WDR advocated the advantages associated with the agglomeration effects of large cities. The Report supported spatially blind strategies able to generate efficiency and development. Barca (2009) and OECD Reports (2009 a, b, c), among others, claim that the objective of development intervention should be to promote growth in all regions and propose a string of place-based interventions (integrated regional policies).

The aim of this paper is twofold: on the one hand we embrace the urban economics and infrastructure literature by assessing the role of different types of infrastructure in the relationship between urban concentration and economic growth. On the other hand we embrace the institutional and policy literature to investigate to what extent public policies have considered the spatial dimension and the connection between infrastructure and agglomeration.

In order to achieve our aims, we first assess the role of the infrastructure-agglomeration interaction on economic growth by means of a panel data analysis considering different measures of infrastructure (as the provision of basic services, transport, and communications). We study differential effects using as case study the European Neighbouring Policy (ENP) countries, EU countries, and the rest of the world. Second, we provide a simple assessment of to what extent the urban structure influences the allocation of funds for infrastructure investment (i.e., whether the allocation these funds is spatially blind or not). For this we analyse the same policy instrument, the funding and lending policies of the European Investment Bank (EIB), for both the EU and ENP countries.

Our results provide evidence on the relevance of the interaction between transport and communications infrastructure and the process of urban concentration on economic development in ENP countries. On the other hand, we do not find an explicit relationship between the urban structure of neighbouring countries and the funding policy of the EIB, in contrast to what takes place in the EU.

The rest of the paper is organised as follows. In the next section we briefly review the ENP. In section 3 we review the association between economic growth and the urban structure of countries, with particular attention to ENP countries, and the role of infrastructure in this relationship. We describe the empirical model and the data we use and present some results. In section 4 we analyse the projects financed by the EIB over the 1995-2010 period. We investigate whether these projects are connected with the spatial structure of our considered countries. In section 5 we conclude with the main outcomes of our research and with several policy implications that can be derived from them. 


\section{The European Neighbouring Policy}

In 2013 Croatia joined the EU and ended the most recent enlargement process. As a consequence, a range of poorer, politically less stable and less democratic countries now border the EU. The EU previewed this process and in 2003 proposed a unified EU policy towards its neighbouring countries aiming at the creation of a ring of friendly, stable and prosperous countries around the EU (see the European Commission communication "The Wider Europe Neighbourhood, A New Framework for Relations with our Eastern and Southern Neighbours" - COM 104 final, 2003). This replaced a former ENP envisioned EU accession for neighbouring countries. In contrast, the new policy offers close political cooperation, economic integration, and access to the unified market, but is not necessarily a pathway to accession.

The start of the current ENP was built on existing policies, allowing for convergence between them. The subsequent multiannual framework (2007-2013) sought to guarantee a coherent institutional structure within the EU. Therefore the ENP added new instruments to all previous policies. Today the ENP is seen not only as a group of policies to promote cooperation between the EU and its neighbours, but also as a tool to project the EU interests to its periphery and to contain negative spillovers and externalities, such as illegal migration or security concerns (Diez 2005; Hyde-Price 2006; Gawrich et al. 2010).

The countries currently under the ENP are: Algeria, Armenia, Azerbaijan, Belarus, Egypt, Georgia, Israel, Jordan, Lebanon, Libya, Moldova, Morocco, Palestine, Syria, Tunisia and Ukraine.

The ENP has a list of policy mechanisms, which, following Wesselink and Boschma (2012), can be summarised in three basic areas. First, the EU provides technical assistance to ENP countries to adapt to EU regulations in order to comply with EU internal market standards (twinning, TAIX or SIGMA, are three examples of such assistance). Second, the EU incentivises changes and reforms on political and economic spheres. The free access to the internal market is an important component of the promise of the ENP on the economic dimension, while the Common Foreign and Security Policy is a significant sign of political cooperation. Other cooperation areas exist, such for universities (Erasmus Mundus), researcher mobility (Tempus), or environmental protection (LIFE+). Finally, the EU can invest in ENP countries through the EIB. While the EIB had an investment mandate for all regions prior to 2002, in 2007 the European Investment Facility (EIF) was founded to leverage funding from the ENP to invest in interregional projects, thus expanding the scope of the EIB. Regional tools also exist: FEMIP for investments in southern countries since 2002, and the Eastern Partners Facility (EPF) for the eastern region since 2009. The policy response to the political turmoil in the spring and summer of 2011 included increasing the investment mandate of the EIB in the southern ENP countries and proposing that the European Bank for Reconstruction and Development (EBRD) would also open up its lending facilities to the southern ENP countries.

A reasonable question is how the ENP is designed and to what extent there is a single 
ENP or a series of bilateral policies between the EU and every ENP country, as highlighted by Wesselink and Boschma (2012), who argue that the lion's share of the funding is earmarked for bilateral programmes. For these authors the EU strives for a differentiated policy, which supports reform in each country in its own speed, with its own priorities and with independent policy objectives. As highlighted by Rodríguez-Pose and Novak (2013), internal introspection and external scrutiny are behind increasing returns of structural funds of European cohesion policy. Thus, for the allocation of EIB funds, learning processes can also result in more appropriate expenditure priorities.

As the specific level of funding across different investment programs is extremely difficult to trace (Wesselink and Boschma 2012), we focus our analysis on the investments managed by the EIB. Some previous papers have attempted at analysing the role of funds given by the EIB to promote growth in Europe (Kollatz-Ahnen 2013; Clifton et al. 2013), while other papers have focused on the role of the EIB outside the EU (Lesay 2013; Langan 2014). ${ }^{5}$ Given the short period of time since the ENP was established it is hard to evaluate the impact on long-run economic growth of infrastructure investments. Consequently, we focus our effort on analysing the design of ENP funding (through the EIB), considering structural characteristics of receiving countries, in particular the spatial distribution of their population and economic activity.

\section{Economic growth, urban structure, and infrastructure}

\subsection{The model}

We follow a neoclassical framework of cross-country economic growth. As in previous papers, we further add a measure for urban concentration. According to Henderson (2003), the degree of urban concentration is a relevant characteristic potentially affecting growth in efficiency. Our empirical specification is given by equation (1): ${ }^{6}$

$$
\gamma_{i t}=\beta\left(\log y_{i, t}\right)+\psi X_{i, t}+\lambda_{1} U C_{i, t}+\lambda_{2} \Delta U C_{i, t}+\pi Z_{1 i, t}+\varepsilon_{i t}
$$

where $\gamma_{i t}$ is per capita average growth rate of economy $i$ in time $t, y_{i, t}$ is initial output per capita, $X_{i, t}$ a vector representing factor accumulation plus a constant term, $U C_{i t}$ is the degree of urban concentration at the beginning of the period, $\Delta U C_{i, t}$ is its growth, $Z_{1 i, t}$ a vector of other country-specific factors explaining cross-country differences in efficiency

\footnotetext{
${ }^{5}$ Clifton et al. (2013) analyse the evolution of EIB loans from prioritizing funding utilities in member's poorer zones to become more oriented in market development. Kollatz-Ahnen (2013) analyse the role of the EIB to foster growth inside the EU in the framework of the current crisis and efforts for recovery. Lesay (2013), relying on Critical Discourse Analysis, study the role of the EIB as a player in development efforts outside the EU. According to Langan (2014) EU-Africa ties through interventions by the EIB, although directed towards poverty reduction, serve more the commercial interests of Europe.

${ }^{6}$ This framework is common in other studies on the relationship between concentration and growth (such as Henderson 2000; Brülhart and Sbergami 2009; and Castells-Quintana and Royuela 2014). Durlauf et al. (2005) provide a detailed explanation of how to derive cross-country growth regressions from neoclassical economic growth theory.
} 
growth (the evolution of technology) or in initial conditions, and $\varepsilon_{i t}$ a country-timespecific error. Following previous papers we allow for a non-linear relationship between urban concentration and growth (the Williamson Hypothesis).

Our focus lies on the coefficients for $U C_{i t}$ and $\Delta U C_{i, t}$, which will capture not only the level of urban concentration but also its growth, these representing a description of the urbanisation process. We analyse differences between ENP countries, European countries, and the rest of the world, as well as the role that different types of infrastructure may play (as discussed in Section 1).

\subsection{Data}

We build a cross-country panel for the period 1995-2010. Our dependent variable is per capita GDP growth, constructed using data from the World Bank database. For urban concentration we follow the literature and use urban primacy. ${ }^{7}$ Data for primacy comes from the World Bank. For national infrastructure several variables are considered. For connectivity infrastructure, we consider measures of transport and communications. For transport we begin with $\mathrm{km}$ of roads per $100 \mathrm{sq}$. $\mathrm{km}$ of land area (road_dens), following previous papers in the applied literature. We also consider $\mathrm{km}$ of roads per $100 \mathrm{sq} . \mathrm{km}$ of agricultural land, as a proxy for habitable land (as many of the ENP countries considered cover extensive arid and even desert areas, empty of people and infrastructure), the proportion of roads that are paved as a proxy for transport infrastructure quality, and road density in terms of population rather than land area, to proxy for congestion. We also look at $\mathrm{km}$ of railroads per $100 \mathrm{sq}$. km of land area (rail_density). For communications we consider the number of telephone lines (teleph), the number of cell phone lines (cell), and the number of broadband subscriptions (internet), all in terms of number per 100 people.

For urban infrastructure, and following the 2011 WDR, we focus on two key indicators: the proportion of urban population with access to improved sanitation (sanitation), and proportion of urban population with access to an improved water source (water). Finally, as control variables ( $X_{i}$ and $Z_{1 i}$ in equation 5), we consider investment as share of GDP (investment) and population growth ( $p o p \_g$ ), which captures the joint effect of fertility and migration processes. Other usual controls, such as fertility rates, and average years of secondary and higher education of the adult population (as in Henderson 2000), were discarded as they would imply a large loss of observations.

To assess the role of the ENP we look at investments from the EIB. We compile data on investment projects (number and total amount) by country, looking at the different sectors where investments are made. Variables sources and definitions are displayed in Annex 1,

\footnotetext{
${ }^{7}$ Primacy measures consider main metropolitan areas (including core city and satellite cities), a central concept for agglomeration economies and congestion costs. It has been shown that primacy correlates very highly with other measures of concentration (as the Hirschman-Herfindahl index for which there is very limited coverage) and reflects fairly well parameters behind Zipf's law curves (the fact that when we rank cities from largest to smallest, rank times population size is approximately the same constant for all cities). The largest city in the country, therefore, delineates all other city sizes and is sufficient information to calculate any comparative index of national urban concentration (Henderson 2003).
} 
while Annex 2 describes the EIB information. The data correspond to the 1995-2010 period, and is disaggregated geographically, distinguishing between southern and eastern ENP countries. Likewise, it is interesting to compare both groups with world averages as well as with EU15 averages, but it is particularly interesting to compare them with previous ENP countries. Consequently we also describe the main statistics of the 2004enlargment countries. ${ }^{8}$ Supplementary Material A provides descriptive statistics by region for our key variables.

\section{Figure 1: Dynamic (1995-2010) scatterplot of GDP per capita and Primacy, by region}

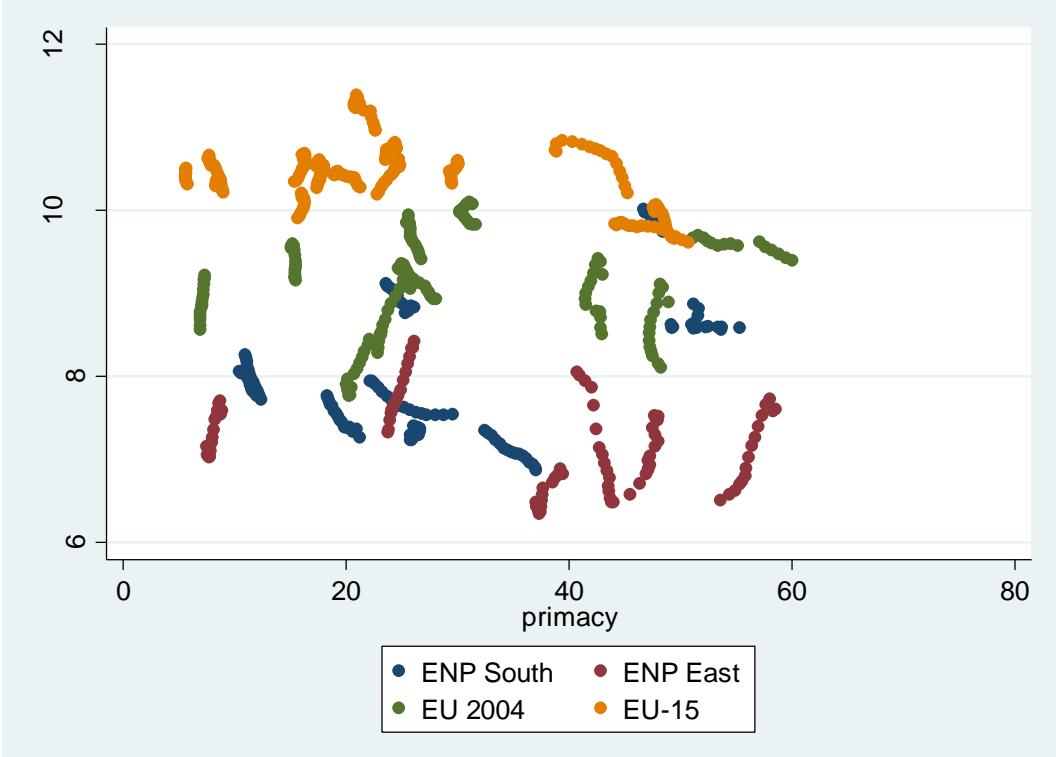

Figure 1 presents a scatterplot of GDP per capita and urban concentration (primacy). Looking at income and growth over our period of analysis, ENP countries have income close to the world average, but lower than EU15 and also lower than the 2004-enlargment countries. On average, southern ENP countries are richer than eastern ENP countries, although the latter display faster economic growth over the analysed period (implying unconditional convergence among the two groups). Indeed, although growth has been significantly high in almost all ENP countries (with an average of 4\% for the 1995-2010 period), eastern ENP countries have grown substantially more (around 6\% per year) than southern ENP countries (2.5\%). As a group, ENP countries have displayed growth rates around 1.5\% higher than the world average, around 2\% higher than the EU15 average, and slightly higher than the 2004-enlargement countries average. ${ }^{9}$

\footnotetext{
${ }^{8}$ Ten countries joined the EU in 2004: Cyprus, the Czech Republic, Estonia, Hungary, Latvia, Lithuania, Malta, Poland, Slovakia, and Slovenia. Bulgaria and Romania joined in 2007 and according to the Commission, constitute part of the fifth enlargement. Finally, in 2013, Croatia became the $28^{\text {th }}$ member state of the EU.

${ }^{9}$ By country, Israel displays the highest GDP per capita levels among all ENP countries; Moldova and Azerbaijan the lowest. Belarus is the richest among the Eastern ENCs and Egypt is the poorest among the Southern ENCs. Regarding growth rates, Azerbaijan displayed the highest among all ENCs while Israel
} 
Figure 2: Distribution of primacy, by geographical regions

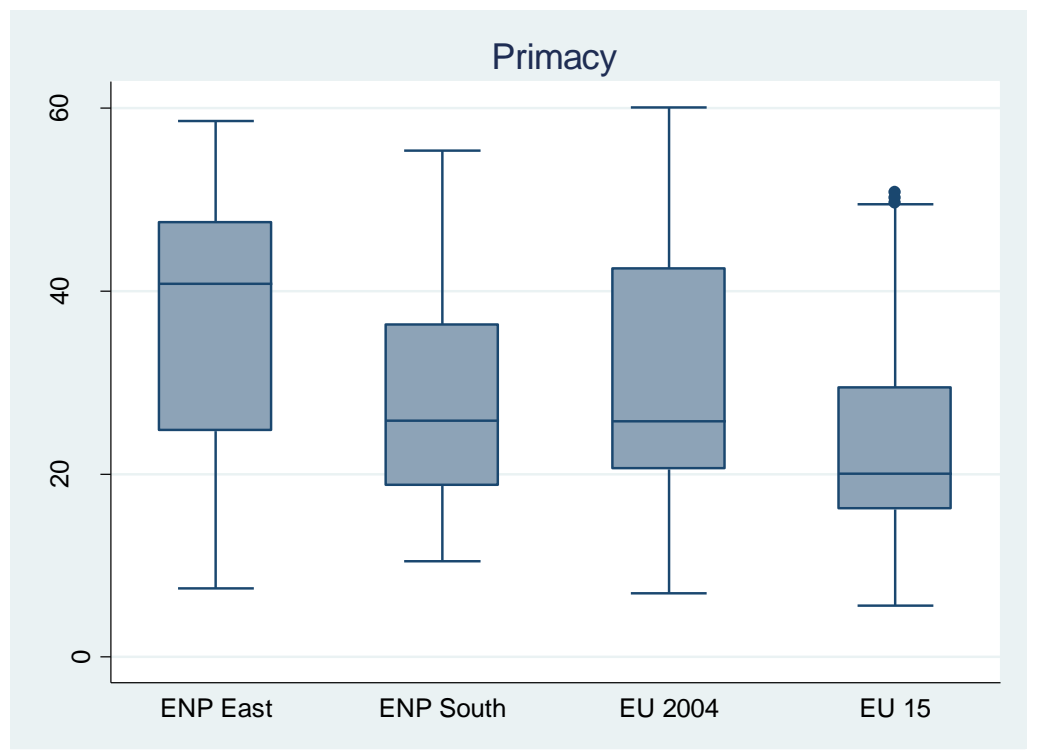

Figure 2 shows the distribution of primacy for the EU and its neighbours. Looking at urban concentration, new EU members and eastern ENP countries have a higher proportion of urban population living in the largest city, while the EU15 have lower levels. Higher levels of concentration in eastern ENP countries than in EU15 countries are not surprising as de-concentration is expected with higher levels of development. Both the EU15 and eastern ENP countries show a positive correlation between primacy and economic growth, while EU2004 countries show zero correlation and southern ENP countries a weakly negative correlation. ${ }^{10}$

Variables associated with urban infrastructure, as well as those related to access to basic services, enjoy high averages (close to $100 \%$ of the population having access to such services) both in the EU and its neighbours. On the contrary, other variables associated with connectivity, such as telephone lines, mobile cellular subscriptions, and different measurements of road density, have a wider variation over geographical areas, with significantly higher levels in the EU than in ENP countries. ENP countries display substantially lower values in many measures of connectivity, even when compared to world averages.

\subsection{Estimation and Results}

We split the 1995-2010 sample into 3-year periods to reduce noise from the business cycle. As explained above, we estimate the effect that the process of urban concentration

displayed the lowest. Tunisia was the fastest growing among the Southern ENCs and Moldova was the slowest growing among Eastern ENCs.

${ }^{10}$ Armenia has the highest level of concentration among all ENPs, while Ukraine has the lowest. Among the Southern ENCs, Lebanon is the country with highest concentration and Tunisia the country with the lowest. 
has on economic growth, controlling, among other things, for initial levels of concentration (taking into account that the relationship between concentration and growth changes with the process of development - the Williamson hypothesis). Table 1 presents our results. All controls have the expected sign and are significant. Regarding $\Delta U C_{i, t}$, its coefficient is negative and significant (column 1). If we let the coefficient vary between our considered world regions (column 2) we find that the negative association becomes economically and statistically stronger for the ENP countries. By contrast, for EU15 countries the relationship is opposite, with a positive and significant coefficient. In columns 3 and 4 we let the association between $\Delta U C_{i, t}$ and economic growth depend on infrastructure variables. We present results for road_dens. As noted before, national infrastructure defining connectivity in the national urban system is expected to be a fundamental determinant of agglomeration economies. For ENP countries and EU15 countries we find a negative and significant coefficient for $\Delta U C_{i, t}$ but a positive and significant coefficient for its interaction with road_dens (in logs; column 4). In columns 5, 6 and 7 we replicate the estimations considering only ENP countries. Column 6 shows again a negative coefficient for $\Delta U C_{i, t}$ and a positive coefficient for the interaction, both coefficients being highly significant. The same result is also found when we differentiate between eastern and southern ENP countries, although the association is clearly stronger for eastern ENP countries (column 7).

Finally, in order to address potential endogeneity concerns we estimate our model for ENP countries using an IV-GMM approach. ${ }^{11}$ Results support our previous findings: a negative and significant coefficient for $\Delta U C_{i, 0}$ and a positive and significant interaction with road_dens (logged). ${ }^{12}$

Results of Table 1 highlight the expected growth-reducing congestion costs associated with the process of urban concentration. The results, however, also suggest the role of connectivity within the urban system. The positive effect of the interaction between connectivity infrastructure and the process of concentration highlights the relevance of the development of this infrastructure for the national-wide benefits of agglomeration. In particular, our results point towards a relevant role for transport infrastructure (i.e road_dens) in the ENP countries.

\footnotetext{
${ }^{11}$ For main tables and discussion of results we have preferred to rely on our FE results for three main reasons. First, as we aggregate our data in 3-year periods, we have a small T (around 5 periods). IV-GMM estimations relying on lags imply an important loss of observations. Second, this also implies using variable transformations as instruments without a strong explanatory power. Finally, and related, the number of instruments becomes too large relative to the number of observations.

12 Supplementary Material B reproduces main FE results in Table 1 showing: (i) coefficients for all considered controls, (ii) results without controls, and (iii) some IV-GMM results. Controls appear with the expected sign and tend to be highly significant. Additionally, main results do not seem to be affected by the inclusion/exclusion of the considered controls.
} 
Table 1: Urban concentration and growth

\begin{tabular}{|c|c|c|c|c|c|c|c|}
\hline & (1) World & (2) World & (3) World & (4) World & (5) ENPs & (6) ENPs & (7) ENPs \\
\hline$\Delta \mathrm{UC}$ & $\begin{array}{c}-0.1408 * * \\
(0.0567)\end{array}$ & $\begin{array}{c}-0.1350 * * \\
(0.0594)\end{array}$ & $\begin{array}{c}0.082 \\
(0.6631)\end{array}$ & $\begin{array}{c}0.2608 \\
(0.7619)\end{array}$ & $\begin{array}{c}-1.9378 * * * \\
(0.4906)\end{array}$ & $\begin{array}{c}-64.9839 * * * \\
(20.9612)\end{array}$ & \\
\hline$\Delta \mathrm{UC} * \mathrm{ENPs}$ & & $\begin{array}{c}-1.4437 * * * \\
(0.4160)\end{array}$ & & $\begin{array}{l}-35.7100^{*} \\
(21.1012)\end{array}$ & & & \\
\hline$\Delta U C * E U 2004$ & & $\begin{array}{c}-1.3556 * * \\
(0.6118)\end{array}$ & & $\begin{array}{l}-4.2494 \\
(2.9988)\end{array}$ & & & \\
\hline$\Delta \mathrm{UC} * \mathrm{EU} 15$ & & $\begin{array}{l}2.3327^{*} \\
(1.3568)\end{array}$ & & $\begin{array}{c}-7.0465 * * \\
(3.4635)\end{array}$ & & & \\
\hline$\Delta \mathrm{UC} *$ Road_dens & & & $\begin{array}{l}-0.2340 \\
(0.1724)\end{array}$ & $\begin{array}{l}-0.2209 \\
(0.2179)\end{array}$ & & $\begin{array}{c}19.4401 * * \\
(6.6170)\end{array}$ & \\
\hline$\Delta \mathrm{UC} *$ Road_dens*ENPs & & & & $\begin{array}{l}9.8432 * \\
(5.7308)\end{array}$ & & & \\
\hline$\Delta U C *$ Road_dens*EU2004 & & & & $\begin{array}{c}0.5353 \\
(0.5626)\end{array}$ & & & \\
\hline$\Delta U C *$ Road_dens*EU15 & & & & $\begin{array}{c}2.0962 * * \\
(0.8207)\end{array}$ & & & \\
\hline Road_dens & & & $\begin{array}{c}3.3575 \\
(2.8084)\end{array}$ & $\begin{array}{l}2.7713 \\
(2.7247)\end{array}$ & & $\begin{array}{c}24.7167 \\
(27.6503)\end{array}$ & $\begin{array}{c}8.7437 \\
(24.2911)\end{array}$ \\
\hline$\Delta \mathrm{UC} * \mathrm{ENPEast}$ & & & & & & & $\begin{array}{c}-135.2493 * * * \\
(36.3200)\end{array}$ \\
\hline$\Delta \mathrm{UC} *$ ENPSouth & & & & & & & $\begin{array}{c}-52.2609^{*} \\
(27.2182)\end{array}$ \\
\hline$\Delta \mathrm{UC} *$ Road_dens*ENPEast & & & & & & & $\begin{array}{c}40.2985 * * * \\
(10.5956)\end{array}$ \\
\hline$\Delta \mathrm{UC} *$ Road_dens*ENPSouth & & & & & & & $\begin{array}{l}27.2008^{*} \\
(14.3187)\end{array}$ \\
\hline Controls & YES & YES & YES & YES & YES & YES & YES \\
\hline Country Fixed Effects & YES & YES & YES & YES & YES & YES & YES \\
\hline Year Fixed Effects & YES & YES & YES & YES & YES & YES & YES \\
\hline R-sq (within) & 0.421 & 0.436 & 0.671 & 0.703 & 0.568 & 0.865 & 0.912 \\
\hline Obs. (countries) & $673(173)$ & $673(173)$ & $285(122)$ & $285(122)$ & $58(15)$ & $32(13)$ & $32(13)$ \\
\hline
\end{tabular}

Notes: The dependent variable is GDP per capita growth. Results using road_dens (in logs) as proxy for connectivity infrastructure.

Estimations use robust standard errors (showed in parenthesis). Significance: $* \mathrm{p}<0.10, * * \mathrm{p}<0.05, * * \mathrm{p}<0.01$ 
We experimented with the several variables for connectivity infrastructure and others related to basic urban infrastructure (as described in section 3.2). Annex 3 shows results for telephone lines, as a measure for communication infrastructure, and for access to improved sanitation, as a measure for basic urban infrastructure. For ENP countries, results with other variables for connectivity infrastructure (i.e. transport and communication) are in line with our main results. Other variables (those related to basic services) appear as significant on their own but not when interacted with $\Delta U C_{i, t}$. This may indicate that these variables are significant determinants of growth in ENP countries but that they do not play a significant role for agglomeration benefits, or a at least not at the current stage of development (contrary to what happens with connectivity infrastructure, most of ENP countries display high levels of access to basic services).

\section{Analysis of the EIB funding scheme for infrastructures}

In the previous section we have shown how infrastructure plays a role in economic development not only by itself but also as promoting the full advantage of agglomeration economies: we have seen that infrastructure is important per se, but also matters in so far as it interacts with the urbanisation process. In this section we revisit whether the EIB has considered the spatial issues associated with the process of development, particularly in ENP countries.

Table 2 describes the sector and geographical allocation of the 18,488 EIB projects that we identified, while Figure 3 plots the proportion of the budget by geographical area of destination. Clearly most projects are directed to Credit lines. Energy and Industry were surpassed by Transportation projects after 1995 (being most of them linked to interurban connections). Other areas with increasing importance are Urban Development, Education, and Health. Countries that last joined the EU have increased both the number of projects and also the share of the EIB budget. On the contrary, southern ENP countries have experienced a decrease in recent years. Eastern ENP countries started receiving funds from EIB projects in 2007. In 2013, eastern ENP countries had more projects than southern ENP countries, although the amount of money was still below the funding for southern ENP countries.

It is beyond the scope of this paper to analyse EIB policy on the allocation of funds among different countries, sectors and over time. We can, however, assess to what extent we can explain the funds allocated by means of vectors of dummies related to the country and to the sector of each project, as well as to the year when the funds were allocated:

$$
E I B_{i t}=\beta_{0}+\text { Countries } \boldsymbol{B}_{1}+\text { Sectors } \boldsymbol{B}_{2}+\text { Years } \boldsymbol{B}_{3}+\varepsilon_{i t}
$$

where $E I B_{i t}$ represents the amount financed by EIB projects for country $i$ in time $t$, and $\varepsilon_{i t}$ a country-time-specific error. What this specification allows us to do is to analyse if the spatial dimension of the countries where the projects have been assigned was taken into account by including in the equation measures related to the spatial structure of 
population and economic activity within countries. Thus, we include a vector of urban characteristics for every country (Urban), which includes the proportion of people living in the largest city (primacy) and the proportion of people living in urban areas (urbanisation):

$$
E I B_{i t}=\beta_{0}+\text { Countries } \boldsymbol{B}_{1}+\text { Sectors } \boldsymbol{B}_{2}+\text { Years } \boldsymbol{B}_{3}+\text { Urban } \boldsymbol{\Delta}+\varepsilon_{i t}
$$

Table 2: Volume of EIB projects by sector and geographical area

\begin{tabular}{|c|c|c|c|c|}
\hline Sector & \multicolumn{2}{|c|}{ 1959-1995 } & \multicolumn{2}{|c|}{ 1995-2013 } \\
\hline Telecom * & 375 & $4.7 \%$ & 372 & $3.5 \%$ \\
\hline Composite infrastructure $*$ & 159 & $2.0 \%$ & 163 & $1.5 \%$ \\
\hline Education & 16 & $0.2 \%$ & 356 & $3.4 \%$ \\
\hline Health & 2 & $0.0 \%$ & 320 & $3.0 \%$ \\
\hline Solid waste * & 101 & $1.3 \%$ & 138 & $1.3 \%$ \\
\hline Transport $*$ & 1169 & $14.7 \%$ & 2093 & $19.8 \%$ \\
\hline Urban development $*$ & 65 & $0.8 \%$ & 399 & $3.8 \%$ \\
\hline Water, sewerage * & 663 & $8.4 \%$ & 651 & $6.2 \%$ \\
\hline Agriculture, fisheries, forestry & 64 & $0.8 \%$ & 65 & $0.6 \%$ \\
\hline Energy & 1350 & $17.0 \%$ & 1236 & $11.7 \%$ \\
\hline Industry & 1523 & $19.2 \%$ & 1241 & $11.8 \%$ \\
\hline Services & 224 & $2.8 \%$ & 448 & $4.2 \%$ \\
\hline Credit lines & 2216 & $28.0 \%$ & 3079 & $29.2 \%$ \\
\hline Total & 7927 & $100.0 \%$ & 10561 & $100.0 \%$ \\
\hline Region & \multicolumn{2}{|c|}{ 1959-1995 } & \multicolumn{2}{|c|}{$1995-2013$} \\
\hline Africa & 572 & $7.2 \%$ & 457 & $4.3 \%$ \\
\hline America & 105 & $1.3 \%$ & 178 & $1.7 \%$ \\
\hline Asia & 76 & $1.0 \%$ & 278 & $2.6 \%$ \\
\hline Oceania & 75 & $0.9 \%$ & 36 & $0.3 \%$ \\
\hline ENP - East & 0 & $0.0 \%$ & 51 & $0.5 \%$ \\
\hline ENP - South & 195 & $2.5 \%$ & 357 & $3.4 \%$ \\
\hline EU15 & 6775 & $85.5 \%$ & 7567 & $71.7 \%$ \\
\hline EU2004 & 90 & $1.1 \%$ & 1433 & $13.6 \%$ \\
\hline Northern Europe & 20 & $0.3 \%$ & 34 & $0.3 \%$ \\
\hline Russia & 0 & $0.0 \%$ & 19 & $0.2 \%$ \\
\hline Southern Europe & 19 & $0.2 \%$ & 144 & $1.4 \%$ \\
\hline Western Europe & 0 & $0.0 \%$ & 7 & $0.1 \%$ \\
\hline Total & 7927 & $100.0 \%$ & 10561 & $100.0 \%$ \\
\hline
\end{tabular}

Note: sectors with * are classified as sectors linked with infrastructure affecting the urban structure. 
Figure 3: Proportion of the budget of EIB projects by geographical area

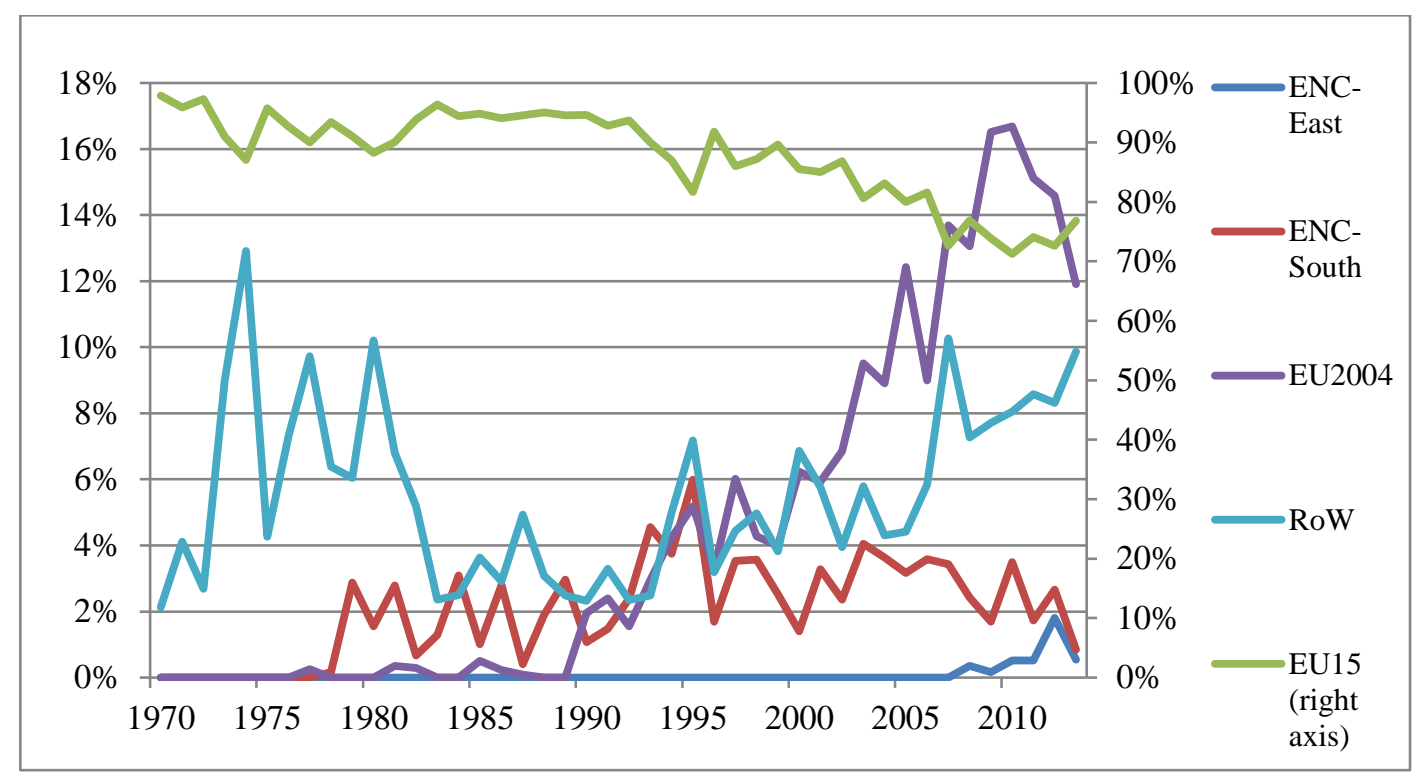

The results are displayed in Table 3. First of all, we can see that such a parsimonious model explains a far higher variation of the allocation of all projects in countries not belonging to the EU. Indeed, the adjustment of the models $\left(\mathrm{R}^{2}\right)$, for the ENP countries and the rest of the world, is usually above 50\%, while that for EU15 and 2004enlargement countries is in general below 30\%. Once differences are assumed, results suggest that the urban structure has been considered in the projects implemented in the EU, both for EU15 and EU2004 countries. On the contrary, the urban structure for the rest of countries is not significant in explaining how funds are allocated. These results apply particularly to the projects excluding the 'Credit Lines' concept, and is also present for the projects associated with sectors more or less linked to urban issues or to infrastructures (Water, sewerage; Solid Waste; Telecom; Composite infrastructures; Transport; and Urban development). The parameter associated with primacy is positive and significant for EU15 and EU2004 (projects excluding credit lines and projects associated with infrastructure), while the one associated with urbanisation is negative for EU15 and positive for EU2004 (projects excluding credit lines).

We assume that it is hard to evaluate the EIB policy as a spatial policy. As mentioned in section 2, the EIB can be seen as one of the mechanisms linked to the ENP. The EIB basically finances high quality projects and its nature is not a development policy. In our view, any major development policy, irrespective of its specific aim, is expected to have a spatial impact, and consequently it is a key issue to consider its spatial consequences.

For EU countries our naïve estimates point towards some sort of association between urbanisation patterns and EIB funding, being robust the positive result with primacy. On the contrary, the estimates report no significant results for urbanisation measures for ENP and rest of the world countries. These results do not imply that the EIB is not considering 
spatial consequences in the allocation of funds. Many projects are indeed linked to transport, urban development, etc. Moreover, the allocation of funds by the EIB in the EU is not only driven by country, sector or period issues, but the spatial dimension also seems to be explicitly considered. In ENP countries, however, the allocation of projects and funds by the EIB seems much more tailored to country, temporal, or sectoral characteristics. The bilateral nature of the relationships between the EU and the ENC (and also with other countries of the world) masks the possibility of finding a significant impact of the spatial structure of the countries as an aspect linked with the financed projects.

Wesselink and Boschma (2012) argue that the ENP is a bilateral program, with specific and independent priorities and policy objectives for every country. Our results support this view and stress the fact that these specificities hide any possible global spatial agenda on the part of the EU.

\section{Discussion and Conclusion}

In this paper we review the association between urban concentration and economic growth. In this regard we assess the role of infrastructure in this relationship. We consider measures of urban infrastructure as well as measures of connectivity (i.e. transport and communications). We use panel data over 15 years with a geographical focus on the ENP countries, comparing our results for these countries with other regions: the 2004enlargement countries, the EU15 countries, and the rest of the world. Our results suggest a relevant role for connectivity infrastructure in agglomeration economies. For ENP countries, transport infrastructure, for which these countries still display relatively low values, is identified as critical.

We have also analysed the allocation of funding by the EIB by country and sector over time. We find evidence that the ENP is a bilateral program, where any possible global agenda related to spatial issues is masked by country-specific priorities and policy objectives. Given our results on urban patterns, infrastructure development and economic performance, development assistance should more strongly take into account the spatial structure of economic activity in receiving countries, something the EIB does not seem to be doing when allocating funds and projects outside the EU. The spatial dimension clearly brings relevant concerns in regards the allocation of funds only based on each project's individual performance to the extent that overall effects within countries in economic, social, and territorial terms could be under estimated. 
Table 3: EIB projects estimates

\begin{tabular}{|c|c|c|c|c|c|c|c|c|}
\hline & EU15 & EU2004 & ENP & $\begin{array}{c}\text { Rest of } \\
\text { the World }\end{array}$ & EU15 & EU2004 & ENP & $\begin{array}{c}\text { Rest of } \\
\text { the World }\end{array}$ \\
\hline Primacy & 0.046955 & -0.003326 & 0.021700 & -0.027487 & 0.046666 & 0.036858 & 0.048820 & -0.026555 \\
\hline \multirow[t]{2}{*}{ Urbanisation } & $-0.068641 * * *$ & 0.092069 & -0.053248 & -0.025895 & $-0.069194 * * *$ & 0.080955 & -0.062878 & -0.027828 \\
\hline & $(0.017203)$ & $(0.066052)$ & $(0.056891)$ & $(0.028408)$ & $(0.017213)$ & $(0.067295)$ & $(0.059177)$ & $(0.029163)$ \\
\hline Controls & NO & NO & NO & NO & YES & YES & YES & YES \\
\hline \multirow[t]{2}{*}{$\operatorname{adj} R^{2}$} & 0.179 & 0.238 & 0.468 & 0.592 & 0.179 & 0.238 & 0.471 & 0.591 \\
\hline & \multicolumn{8}{|c|}{ ALL PROJECTS, EXCLUDING CREDIT LINES } \\
\hline \multirow[t]{2}{*}{ Primacy } & $0.081894 * *$ & $0.199128^{*}$ & -0.080245 & -0.046013 & $0.082604 * *$ & $0.257481 * *$ & -0.087119 & -0.044600 \\
\hline & $(0.036901)$ & $(0.112310)$ & $(0.070785)$ & $(0.043020)$ & $(0.036907)$ & $(0.127197)$ & $(0.076886)$ & $(0.044459)$ \\
\hline Urbanisation & $-0.036665^{*}$ & $0.217166^{* *}$ & -0.080045 & 0.014686 & $-0.037554^{*}$ & $0.198795^{* *}$ & -0.077891 & 0.015528 \\
\hline $\operatorname{adj} R^{2}$ & \multicolumn{8}{|c|}{ PROJECTS ASSOCIATED WITH INFRASTRUCTURE } \\
\hline \multirow[t]{2}{*}{ Primacy } & $0.111139 * *$ & $0.236691 *$ & -0.063607 & -0.018763 & $0.112357 * *$ & 0.210812 & -0.073611 & -0.038959 \\
\hline & $(0.047148)$ & $(0.124063)$ & $(0.085393)$ & $(0.070034)$ & $(0.047173)$ & $(0.149071)$ & $(0.097607)$ & $(0.077189)$ \\
\hline \multirow[t]{2}{*}{ Urbanisation } & 0.041742 & 0.147024 & -0.092419 & 0.051343 & 0.044402 & 0.150905 & -0.036320 & 0.038047 \\
\hline & $(0.027647)$ & $(0.115542)$ & $(0.136511)$ & $(0.053641)$ & $(0.027826)$ & $(0.116368)$ & $(0.152069)$ & $(0.055913)$ \\
\hline $\mathrm{N}$ & 2299 & 342 & 116 & 286 & 2299 & 342 & 111 & 273 \\
\hline $\mathrm{R}^{2}$ & 0.237 & 0.247 & 0.425 & 0.632 & 0.237 & 0.247 & 0.431 & 0.624 \\
\hline $\operatorname{adj} R^{2}$ & 0.225 & 0.175 & 0.203 & 0.486 & 0.225 & 0.172 & 0.197 & 0.472 \\
\hline
\end{tabular}

Note: The endogenous variable is the log of the amount financed by EIB projects (in $€$ ). The period of analysis is $1995-2010$.

All estimates include country, year and project sector dummies. 


\section{References}

Anderson, W., and Lakshmanan, T. (2007) 'Infrastructure and productivity What are the underlying mechanisms?' in Karlsson, C., Anderson, W., Johansson, B., and Kobayashi, K. (Eds.) The Management and Measurement of Infrastructure, Eduard-Elgar, Northhampton, pp. 147-162.

Barca, F. (2009) 'An Agenda for A Reformed Cohesion Policy: A Place-Based Approach to Meeting European Union Challenges and Expectations,' Independent Report, Prepared at the Request of the European Commissioner for Regional Policy, Danuta Hübner, European Commission, Brussels.

Barca, F., McCann, P., and Rodríguez-Pose, A. (2012). 'The case for regional development intervention: Place-based versus place-neutral approaches,' Journal of Regional Science 52(1): 134-152.

Bertinelli, L., and Black, D. (2004). 'Urbanization and growth,' Journal of Urban Economics 56: 80-96.

Blundell, R., and Bond, S. (1998). 'Initial conditions and moment restrictions in dynamic panel data models,' Journal of Econometrics 87(1): 115-143.

Brülhart, M., and Sbergami, F. (2009). 'Agglomeration and growth: Cross-country evidence,' Journal of Urban Economics 65: 48-63.

Camagni, R., Capello, R., and Caragliu, A. (2013). 'One or infinite optimal city sizes? In search of an equilibrium size for cities,' Annals of Regional Science 51: 309-341.

Capello, R., and Camagni, R. (2000). 'Beyond optimal city size: An evaluation of alternative urban growth patterns,' Urban Studies 37: 1479.

Castells-Quintana, D., and Royuela, V. (2014). 'Agglomeration, inequality and economic growth,' Annals of Regional Science 52(2): 343-366.

Clifton, J., Diaz-Fuentes, D., and Revuelta, J. (2013). Financing utilities: How the role of the European Investment Bank shifted from regional development to making markets. SSRN Working Paper.

Diez T. (2005), Constructing the Self and Changing Others: Reconsidering 'Normative Power Europe', Millennium: Journal of International Studies 33(3), 613-36.

Duranton, G. and D. Puga. (2000). 'Diversity and specialization in cities: why, where and when does it matter?' Urban Studies 37: 533-55.

Durlauf, S., Johnson, P. and Temple, J. 2005. 'Growth Econometrics,' in Philippe Aghion and Steven Durlauf (Eds.), Handbook of Economic Growth, Elsevier: 255-677.

Estache, A. (2010) "Infrastructure finance in developing countries: An overview" EIB Papers, (15:2), pp. 60-88.

European Commission (2003) The Wider Europe Neighbourhood, A New Framework for Relations with our Eastern and Southern Neighbours, European Commission (COM 104 final). Available at http://eeas.europa.eu/enp/pdf/pdf/com03 104_en.pdf

Fujita, M., Krugman, P., Venables, A. (1999) The spatial economy. MIT Press, Cambridge.

Gawrich A., Melnykovska I. and Schweickert R. (2010), Neighbourhood Europeanization through ENP: The Case of Ukraine, Journal of Common Market Studies, 48(5), 1209-1235.

Gifford, J.L. (1996) 'Complexity, adaptability and flexibility in infrastructure and regional development: insights and implications for policy analysis and planning', in Batten, D.F. and Karlsson, C. (Eds.) Infrastructure and the complexity of economic development, Springer-Verlag, Heidelberg, pp.169186.

Hakfoort, J. (1996) 'Public capital, private sector productivity and economic growth: a macroeconomic perspective', in Batten, D.F. and Karlsson, C. (Eds.) Infrastructure and the complexity of economic development, Springer-Verlag, Heidelberg, pp.61-74.

Henderson, J.V. (2000). 'The effects of urban concentration on economic growth,' NBER Working Papers Series No. 7503.

Henderson, J.V. (2003). 'The urbanization process and economic growth: The so-what question,' Journal of Economic Growth 8: 47-71.

Henderson, J.V., (2005). 'Urbanization and Growth,' in Philippe Aghion and Steven Durlauf (Eds.), Handbook of Economic Growth, Vol. 1B: 1543-1591.

Hewings, G.J.D. (2014) "Spatially blind trade and fiscal impact policies and their impact on regional economies", Quarterly Review of Economics and Finance, 54 (4), pp. 590-602.

Hyde-Price A. (2006), 'Normative' power Europe: a realist critique, Journal of European Public Policy, 13: 2, 217-234.

Kessides, C. (1996) 'A review of infrastructure's impact on economic development', in Batten, D.F. and Karlsson, C. (Eds.) Infrastructure and the complexity of economic development, Springer-Verlag, Heidelberg, pp. 213-230.

Kollatz-Ahnen, M. (2013). 'European intervention mechanisms for growth: Budget and the European Investment Bank,' Global Policy 4 Issue supplement s1: 41-49. 
Langan, M. (2014). 'A moral economy approach to Africa-EU ties: the case of the European Investment Bank,' Review of International Studies 40: 465-485

Lesay, I. (2013). Discoursing development: the case of the European Investment Bank,' Nova Economia 23(2): 429-462.

Lundqvist, L, Mattsson, LG (2002) "National Transport Models: Introduction and Comparative Analysis", in Lundqvist, L, Mattsson, LG (Ed.) National Transport Models. Recent Developments and Prospects, Springer-Verlag, Heidelberg, pp. 1-16.

Newbery, D. (2012) Energy and Infrastructure, Submission to the LSE Growth Commission.

OECD (2009a) How Regions Grow. Paris Organization for Economic Cooperation and Development

OECD (2009b) Regions Matter: Economic Recovery, Innovation and Sustainable Development. Paris Organization for Economic Cooperation and Development

OECD (2009c) Regions at a Glance. Paris Organization for Economic Cooperation and Development

Ottaviano, G., and Thisse, J-F. (2004). 'Agglomeration and Economic Geography,' in J.V. Henderson and J-F Thisse (Eds), Handbook of Urban and Regional Economics, Edition 1, Vol. 4: 2563-2608.

Rodriguez-Pose, A., and Katja Novak (2013). 'Learning processes and economic returns in European Cohesion policy,' Investigaciones Regionales 25, 7-26.

Romp, W. and de Haan, J. (2007) 'Public Capital and Economic Growth: A Critical Survey', Perspektiven der Wirtschaftspolitik, Verein für Socialpolitik 8(s1): 6-52.

Royuela, V., and Suriñach, J. (2005). 'Constituents of quality of life and urban size,' Social Indicators Research 74: 549-572.

Royuela, V. Moreno, R. and Vayá, E. (2010), 'Influence of Quality of Life on Urban Growth: A Case Study of Barcelona, Spain', Regional Studies, 44(5): 551-567.

Spence, M., Clarke, P., and Buckley, R.M. (Editors). (2009). Urbanization and growth. Commission on growth and development.

Straub, S. (2008). "Infrastructure and growth in developing countries: Recent advances and research challenges". Policy Research Working Paper No. 4460, The World Bank.

Wagenvoort, R., de Nicola, C. and Kappeler, A. (2010). "Infrastructure finance in Europe: Composition, evolution and crisis impact”. EIB Papers, (15:1), pp. 16-39.

Wesselink, E. and Boschma, R. (2012) "Overview of the European Neighbourhood Policy: Its History, Structure, and Implemented Policy Measures", WP1/04 SEARCH working paper.

Williamson, J. (1965). 'Regional inequality and the process on national development,' Economic Development and Cultural Change 4: 3-47.

World Bank (2009) World Development Report 2009: Reshaping economic geography. Washington DC: World Bank.

World Bank. (2011) World Development Report 2011: Conflict, Security and Development. Washington DC: World Bank. 


\section{Annex 1: Variables sources and definitions}

\begin{tabular}{|l|l|l|}
\hline Variable & Description & Source \\
\hline Growth & GDP per capita growth (constant 2005 US\$) & World Bank \\
\hline Income & GDP per capita (constant 2005 US\$) & World Bank \\
\hline Investment & Gross capital formation (\% of GDP) & World Bank \\
\hline pop_g & Total population annual growth rate (three years average) & World Bank \\
\hline Primacy & Population in the largest city (\% of urban population) & World Bank \\
\hline Sanitation & $\begin{array}{l}\text { Improved sanitation facilities, urban (\% of urban } \\
\text { population with access) }\end{array}$ & World Bank \\
\hline Water & $\begin{array}{l}\text { Improved water source, urban (\% of urban population with } \\
\text { access) }\end{array}$ & \\
\hline Teleph & Telephone lines (per 100 people) & World Bank \\
\hline Cell & Mobile cellular subscriptions (per 100 people) & World Bank \\
\hline Internet & Fixed broadband Internet subscribers (per 100 people) & World Bank \\
\hline road_dens & Road density (km of road per 100 sq. km of land area) & World Bank \\
\hline road_dens_2 & $\begin{array}{l}\text { Road density (km of road per 100 sq. km of agricultural } \\
\text { land) }\end{array}$ & World Bank \\
\hline road_paved_dens & $\begin{array}{l}\text { Paved road density (km of paved road per 100 sq. km of } \\
\text { land area) }\end{array}$ & World Bank \\
\hline paved_road & Roads, paved (\% of total roads) & World Bank \\
\hline road_cong & Road congestion (km of road over total population) & World Bank \\
\hline rail_density & Rail lines (total route-km) / Land area (sq. km) & World Bank \\
\hline EIB_proyects & Total amount of EIB projects (€) & $\begin{array}{l}\text { European } \\
\text { Investment Bank }\end{array}$ \\
\hline
\end{tabular}

\section{Annex 2: EIB information}

We recorded EIB projects signed since 1959 until 31/12/2013. The request was done through the EIB website (www.eib.europa.eu/projects/loans/list/index.htm), accessed on the $20^{\text {th }}$ of July 2014 . All projects are assigned to one of the following sectors: 1-Telecom; 2-Composite infrastructures; 3-Education; 4Health; 5-Solid waste; 6-Transport; 7-Urban development; 8-Water, sewerage; 9-Agriculture, fisheries, forestry; 10-Energy; Industry; 11-Services; and 12-Credit lines. We consider the first eight sectors as potentially linked with infrastructure. Each of the 18,913 projects (10,899 projects since 1995) had information on the country, signature date, sector, description (89\% of the projects) and signed amount (in current $€$ ). For the descriptive statistics (see Supplementary material A) we built three alternative indicators of EIB investment:

- As a \% of GDP: we converted EIB investment into US dollars, by using the $2005 € / \$$ exchange rate. Finally we divide this amount by GDP in current US dollars.

- In terms of total population, using the GDP deflator and expressing the investment in terms of 2005 constant US dollars divided by total population.

- In terms of urban population, using the GDP deflator and expressing the investment in terms of 2005 constant US dollars divided by urban population.

All indicators account for a span of five years (current and previous four years) in order to capture the timeto-build effect of investment. 


\section{Annex 3: Result with other infrastructure variables}

\begin{tabular}{lcccc}
\hline & (1) World & (2) ENPs & (3) World & (4) ENPs \\
\hline Dependent variable: & growth & growth & growth & growth \\
\hline$\Delta \mathrm{UC}$ & $-0.349^{* * *}$ & $-6.2156^{*}$ & -0.1909 & -29.4048 \\
& $(0.0634)$ & $(3.1639)$ & $(0.1550)$ & $(19.0154)$ \\
$\Delta \mathrm{UC}^{*}$ Infr & $0.0158^{* * *}$ & 0.2442 & 0.0008 & 0.2827 \\
& $(0.0057)$ & $(0.1563)$ & $(0.0039)$ & $(0.1899)$ \\
Infr & $0.0813^{* * *}$ & 0.0002 & $0.1984 *$ & $1.4820^{* * *}$ \\
& $(0.0271)$ & $(0.1990)$ & $(0.1071)$ & $(0.2462)$ \\
\hline Controls & YES & YES & YES & YES \\
Country Fixed Effects & YES & YES & YES & YES \\
Year Fixed Effects & YES & YES & YES & YES \\
\hline Observations & 669 & 58 & 650 & 58 \\
N. of countries & 172 & 15 & 168 & 15 \\
\hline Notes: In colus
\end{tabular}

Notes: In columns (1) and (2) Infr is teleph. In columns (3) and (4) Infr is sanitation. Estimations using robust standard errors. ${ }^{*} \mathrm{p}<0.10, * * \mathrm{p}<0.05, * * * \mathrm{p}<0.01$ 
Supplementary material A: Descriptive statistics, by region

\begin{tabular}{|c|c|c|c|c|c|c|c|}
\hline & ENP & $\begin{array}{l}\text { ENP } \\
\text { East }\end{array}$ & $\begin{array}{c}\text { ENP } \\
\text { South }\end{array}$ & EU 15 & EU 2004 & ROW & $\begin{array}{c}\text { Whole } \\
\text { Sample }\end{array}$ \\
\hline \multicolumn{8}{|l|}{ GDP per capita growth } \\
\hline Mean (countries) & $3.95(15)$ & $5.97(6)$ & $2.52(9)$ & $1.83(15)$ & $3.8(11)$ & $2.53(175)$ & $2.65(190)$ \\
\hline St Dev & 5.57 & 7.47 & 2.96 & 2.73 & 4.5 & 6.16 & 6.13 \\
\hline between & 2.54 & 2.95 & 0.68 & 0.75 & 1.38 & 2.84 & 2.83 \\
\hline within & 4.98 & 6.97 & 2.89 & 2.63 & 4.3 & 5.48 & 5.44 \\
\hline corr with GDP growth & 1 & 1 & 1 & 1 & 1 & 1 & 1 \\
\hline corr with Primacy & 0.18 & 0.23 & -0.09 & 0.16 & 0.00 & -0.04 & -0.04 \\
\hline \multicolumn{8}{|c|}{ GDP per capita (in logs) } \\
\hline Mean (countries) & $7.72(15)$ & $7.19(6)$ & $8.09(9)$ & $10.42(15)$ & $9.13(11)$ & $8.09(171)$ & $8.06(186)$ \\
\hline St Dev & 0.86 & 0.52 & 0.85 & 0.34 & 0.55 & 1.66 & 1.62 \\
\hline between & 0.85 & 0.41 & 0.89 & 0.34 & 0.53 & 1.66 & 1.61 \\
\hline within & 0.25 & 0.37 & 0.13 & 0.1 & 0.21 & 0.17 & 0.18 \\
\hline corr with GDP growth & -0.09 & 0.23 & -0.02 & -0.06 & -0.21 & -0.04 & -0.05 \\
\hline corr with Primacy & 0.05 & -0.30 & 0.49 & -0.37 & 0.15 & -0.07 & -0.06 \\
\hline \multicolumn{8}{|l|}{ Primacy } \\
\hline Mean (countries) & $31.56(15)$ & $36.24(6)$ & $28.28(9)$ & $23.17(15)$ & $29.29(10)$ & $39.08(172)$ & $38.47(187)$ \\
\hline St Dev & 15.31 & 15.97 & 13.99 & 13.06 & 14.19 & 23.96 & 23.47 \\
\hline between & 15.53 & 17.28 & 14.34 & 13.43 & 14.87 & 24.49 & 23.98 \\
\hline within & 1.09 & 0.9 & 1.21 & 0.91 & 1.12 & 2.34 & 2.27 \\
\hline corr with GDP growth & 0.18 & 0.23 & -0.09 & 0.16 & 0.00 & -0.04 & -0.04 \\
\hline corr with Primacy & 1 & 1 & 1 & 1 & 1 & 1 & 1 \\
\hline \multicolumn{8}{|l|}{ Investment (\% of GDP) } \\
\hline Mean (countries) & $25.06(15)$ & $26.45(6)$ & $24.07(9)$ & $21.14(15)$ & $24.31(11)$ & $23.03(163)$ & $23.2(178)$ \\
\hline St Dev & 6.91 & 7.91 & 5.93 & 3.11 & 5.78 & 11.81 & 11.49 \\
\hline between & 4.06 & 2.87 & 4.5 & 2.4 & 3.68 & 9.77 & 9.42 \\
\hline within & 5.79 & 7.46 & 4.24 & 2.07 & 4.58 & 6.79 & 6.71 \\
\hline corr with GDP growth & 0.22 & 0.20 & 0.14 & 0.25 & 0.49 & 0.38 & 0.37 \\
\hline corr with Primacy & -0.04 & 0.16 & -0.36 & 0.37 & 0.05 & 0.05 & 0.04 \\
\hline \multicolumn{8}{|c|}{ Population growth rate (three year average) } \\
\hline Mean (countries) & $0.97(15)$ & $-0.26(6)$ & $1.84(9)$ & $0.57(15)$ & $-0.1(11)$ & $1.54(175)$ & $1.5(190)$ \\
\hline St Dev & 1.31 & 0.82 & 0.77 & 0.51 & 0.85 & 1.55 & 1.54 \\
\hline between & 1.22 & 0.69 & 0.57 & 0.42 & 0.81 & 1.41 & 1.41 \\
\hline within & 0.54 & 0.53 & 0.55 & 0.31 & 0.33 & 0.75 & 0.73 \\
\hline corr with GDP growth & -0.26 & 0.09 & -0.26 & 0.00 & -0.23 & -0.07 & -0.09 \\
\hline corr with Primacy & -0.01 & 0.20 & 0.43 & 0.18 & 0.00 & 0.08 & 0.08 \\
\hline \multicolumn{8}{|c|}{ Improved sanitation facilities, urban (\% of urban population with access) } \\
\hline Mean (countries) & $93.98(15)$ & $91.33(6)$ & $95.85(9)$ & $99.88(14)$ & $97.49(11)$ & $75.44(168)$ & $76.97(183)$ \\
\hline St Dev & 6.5 & 7.34 & 5.08 & 0.27 & 4.78 & 25.8 & 25.3 \\
\hline between & 6.4 & 7.53 & 5.19 & 0.24 & 5.36 & 25.66 & 25.16 \\
\hline within & 1.65 & 2.47 & 0.61 & 0.15 & 0.4 & 2.56 & 2.5 \\
\hline corr with GDP growth & -0.15 & -0.05 & -0.04 & -0.15 & -0.23 & 0.04 & 0.05 \\
\hline corr with Primacy & -0.03 & -0.22 & 0.39 & -0.76 & -0.31 & -0.04 & -0.05 \\
\hline \multicolumn{8}{|c|}{ Improved water source, urban (\% of urban population with access) } \\
\hline Mean (countries) & $96.71(15)$ & $97.01(6)$ & $96.49(9)$ & $99.91(15)$ & $99.61(11)$ & $92.97(170)$ & $93.26(185)$ \\
\hline St Dev & 5.44 & 4.07 & 6.29 & 0.29 & 0.87 & 9.56 & 9.35 \\
\hline between & 11.58 & 4.39 & 14.58 & 0.28 & 0.84 & 9.35 & 9.52 \\
\hline within & 1.29 & 0.61 & 1.63 & 0.11 & 0.34 & 2.43 & 2.36 \\
\hline corr with GDP growth & -0.02 & -0.23 & 0.20 & -0.04 & -0.16 & -0.09 & -0.08 \\
\hline corr with Primacy & 0.14 & -0.24 & 0.35 & -0.50 & 0.08 & -0.10 & -0.10 \\
\hline
\end{tabular}




\begin{tabular}{|c|c|c|c|c|c|c|c|}
\hline & ENP & $\begin{array}{l}\text { ENP } \\
\text { East }\end{array}$ & $\begin{array}{c}\text { ENP } \\
\text { South }\end{array}$ & EU 15 & EU 2004 & ROW & $\begin{array}{c}\text { Whole } \\
\text { Sample }\end{array}$ \\
\hline \multicolumn{8}{|c|}{ Telephone lines (per 100 people) } \\
\hline Mean (countries) & $17.08(15)$ & $19.91(6)$ & $15.08(9)$ & $51.32(15)$ & $33.92(11)$ & $19.64(175)$ & $19.44(190)$ \\
\hline St Dev & 10.96 & 7.99 & 12.28 & 8.88 & 8.7 & 20.17 & 19.61 \\
\hline between & 10.53 & 7 & 12.36 & 7.6 & 8 & 19.79 & 19.22 \\
\hline within & 3.6 & 4.75 & 2.51 & 4.97 & 4.15 & 3.3 & 3.32 \\
\hline corr with GDP growth & 0.04 & 0.00 & -0.07 & 0.07 & -0.17 & -0.04 & -0.04 \\
\hline corr with Primacy & 0.31 & -0.47 & 0.66 & -0.26 & 0.51 & -0.07 & -0.05 \\
\hline \multicolumn{8}{|c|}{ Cellphones (per 100 people) } \\
\hline Mean (countries) & $33.74(15)$ & $29.16(6)$ & $36.98(9)$ & $75.74(15)$ & $60.66(11)$ & $35.78(175)$ & $35.62(190)$ \\
\hline St Dev & 40.16 & 37.28 & 41.92 & 42.1 & 47.2 & 41.82 & 41.69 \\
\hline between & 18.5 & 7.87 & 23.05 & 9.35 & 8.77 & 25.54 & 25.02 \\
\hline within & 36.13 & 36.57 & 35.95 & 41.11 & 46.45 & 33.26 & 33.49 \\
\hline corr with GDP growth & -0.01 & -0.02 & 0.09 & -0.42 & -0.14 & -0.06 & -0.06 \\
\hline corr with Primacy & -0.02 & -0.15 & 0.11 & -0.04 & -0.07 & -0.08 & -0.07 \\
\hline \multicolumn{8}{|c|}{ Internet (per 100 people) } \\
\hline Mean (countries) & $2.39(15)$ & $1.71(6)$ & $2.82(9)$ & $13.17(15)$ & $7.96(11)$ & $4.41(174)$ & $4.26(189)$ \\
\hline St Dev & 4.94 & 3.18 & 5.78 & 11.74 & 7.78 & 8.33 & 8.15 \\
\hline between & 3.06 & 1.08 & 3.93 & 4.53 & 3.34 & 5.97 & 5.81 \\
\hline within & 3.64 & 3.02 & 4 & 10.89 & 7.12 & 5.69 & 5.56 \\
\hline corr with GDP growth & -0.15 & -0.30 & -0.02 & -0.43 & -0.39 & -0.13 & -0.14 \\
\hline corr with Primacy & 0.23 & -0.20 & 0.46 & -0.25 & 0.22 & -0.08 & -0.06 \\
\hline \multicolumn{8}{|c|}{ Road density, total ( $\mathrm{km}$ of road per $100 \mathrm{sq} . \mathrm{km}$ of land area) } \\
\hline Mean (countries) & $28.15(15)$ & $30.19(6)$ & $25.83(9)$ & $169.1(15)$ & $177.57(11)$ & $100.41(163)$ & $92.45(178)$ \\
\hline St Dev & 19.59 & 6.49 & 27.75 & 118.96 & 187.93 & 180.06 & 171.47 \\
\hline Between & 21.83 & 6.99 & 28.14 & 116.21 & 205.35 & 146.48 & 140.95 \\
\hline within & 1.26 & 0.92 & 1.58 & 4.96 & 36.02 & 17.59 & 16.6 \\
\hline corr with GDP growth & -0.06 & -0.23 & -0.24 & -0.04 & -0.15 & 0.06 & 0.03 \\
\hline corr with Primacy & 0.44 & -0.32 & 0.86 & -0.49 & 0.52 & 0.32 & 0.31 \\
\hline \multicolumn{8}{|c|}{ Roads, paved (\% of total roads) } \\
\hline Mean (countries) & $82.07(15)$ & $84.66(6)$ & $79.95(9)$ & $89.68(15)$ & $66.22(10)$ & $49.8(159)$ & $53.11(174)$ \\
\hline St Dev & 16.47 & 16.09 & 16.57 & 18.49 & 26.72 & 32.94 & 33.12 \\
\hline between & 15.93 & 16.18 & 16.21 & 19.68 & 28.53 & 32.19 & 32.55 \\
\hline within & 5.48 & 6.82 & 4.11 & 1.22 & 5.88 & 5.61 & 5.59 \\
\hline corr with GDP growth & -0.15 & -0.33 & 0.01 & -0.03 & -0.14 & 0.02 & 0.03 \\
\hline corr with Primacy & 0.15 & -0.48 & 0.66 & 0.17 & -0.05 & -0.04 & -0.06 \\
\hline \multicolumn{8}{|c|}{ Road density, paved ( $\mathrm{km}$ of paved road per $100 \mathrm{sq} . \mathrm{km}$ of land area) } \\
\hline Mean (countries) & $25.06(13)$ & $26.1(5)$ & $24.13(8)$ & $159.43(11)$ & $125.82(9)$ & $84.19(145)$ & $77.34(158)$ \\
\hline St Dev & 22.17 & 9.23 & 29.29 & 102.48 & 161.81 & 189.78 & 179.59 \\
\hline between & 20.67 & 9.63 & 25.59 & 99.47 & 199.08 & 142.99 & 137.4 \\
\hline within & 1.83 & 2 & 1.68 & 3.19 & 24.32 & 16.69 & 15.7 \\
\hline corr with GDP growth & -0.11 & -0.31 & -0.20 & -0.15 & -0.18 & 0.11 & 0.07 \\
\hline corr with Primacy & 0.52 & -0.43 & 0.89 & -0.24 & 0.58 & 0.40 & 0.41 \\
\hline \multicolumn{8}{|c|}{ Road paved density (km of road per $100 \mathrm{sq} . \mathrm{km}$ of agricultural land) } \\
\hline Mean (countries) & $78.98(13)$ & $44.96(5)$ & $109.08(8)$ & $352.94(11)$ & $431.62(9)$ & $802.79(143)$ & $717.02(156)$ \\
\hline St Dev & 101.24 & 21.37 & 130.87 & 195.85 & 561.82 & 4702.05 & 4420.65 \\
\hline between & 97.63 & 21.04 & 122.74 & 191.34 & 675.91 & 3164.38 & 3030.54 \\
\hline within & 17.45 & 5.47 & 23.52 & 9.54 & 104.27 & 985.03 & 924.77 \\
\hline corr with GDP growth & -0.19 & -0.15 & -0.12 & -0.09 & -0.20 & 0.02 & 0.01 \\
\hline corr with Primacy & 0.54 & -0.26 & 0.91 & -0.41 & 0.63 & 0.41 & 0.41 \\
\hline
\end{tabular}




\begin{tabular}{|c|c|c|c|c|c|c|c|}
\hline & ENP & $\begin{array}{l}\text { ENP } \\
\text { East }\end{array}$ & $\begin{array}{c}\text { ENP } \\
\text { South }\end{array}$ & EU 15 & EU 2004 & ROW & $\begin{array}{c}\text { Whole } \\
\text { Sample }\end{array}$ \\
\hline \multicolumn{8}{|c|}{ Road congestion ( $\mathrm{km}$ of road over total population) } \\
\hline Mean (countries) & $-4.92(15)$ & $-4.84(6)$ & $-5(9)$ & $-3.72(15)$ & $-3.61(11)$ & $-4.46(158)$ & $-4.51(173)$ \\
\hline St Dev & 0.38 & 0.4 & 0.35 & 0.63 & 0.68 & 1.02 & 0.98 \\
\hline between & 0.61 & 0.47 & 0.71 & 0.68 & 0.71 & 1 & 0.98 \\
\hline within & 0.09 & 0.07 & 0.1 & 0.14 & 0.12 & 0.13 & 0.13 \\
\hline corr with GDP growth & -0.05 & -0.12 & -0.19 & 0.16 & 0.06 & -0.02 & -0.03 \\
\hline corr with Primacy & -0.18 & -0.32 & -0.17 & -0.07 & 0.22 & -0.20 & -0.19 \\
\hline \multicolumn{8}{|c|}{ Rail lines (total route-km) / Land area (sq. km) } \\
\hline Mean (countries) & $-4.42(13)$ & $-3.57(6)$ & $-5.06(7)$ & $-3.09(15)$ & $-2.95(9)$ & $-4.29(95)$ & $-4.31(108)$ \\
\hline St Dev & 1.02 & 0.2 & 0.92 & 0.6 & 0.53 & 1.39 & 1.35 \\
\hline between & 1.06 & 0.2 & 1.02 & 0.63 & 0.56 & 1.43 & 1.39 \\
\hline within & 0.1 & 0.04 & 0.12 & 0.05 & 0.06 & 0.13 & 0.13 \\
\hline corr with GDP growth & 0.24 & -0.35 & 0.00 & -0.17 & -0.15 & -0.01 & 0.02 \\
\hline corr with Primacy & 0.41 & -0.71 & 0.55 & -0.58 & -0.59 & -0.22 & -0.14 \\
\hline \multicolumn{8}{|c|}{ Number of EIB projects in sectors linked to infrastructure. 5 year average } \\
\hline Mean (countries) & $2.65(15)$ & $0.18(6)$ & $4.39(9)$ & $60.4(15)$ & $10.84(11)$ & $6.56(175)$ & $6.25(190)$ \\
\hline St Dev & 3.69 & 0.65 & 3.95 & 52.68 & 12.52 & 23.33 & 22.45 \\
\hline between & 3.33 & 0.25 & 3.49 & 50.02 & 9.52 & 22.15 & 21.3 \\
\hline within & 1.73 & 0.61 & 2.21 & 20.75 & 8.6 & 6.61 & 6.36 \\
\hline corr with GDP growth & -0.15 & -0.10 & 0.09 & -0.11 & -0.09 & -0.03 & -0.03 \\
\hline corr with Primacy & -0.39 & -0.14 & -0.41 & -0.37 & -0.59 & -0.23 & -0.22 \\
\hline \multicolumn{8}{|c|}{ Number of EIB projects in other sectors. 5 year average } \\
\hline Mean (countries) & $4.13(15)$ & $0.1(6)$ & $6.96(9)$ & $70.28(15)$ & $10.81(11)$ & $8.14(175)$ & $7.83(190)$ \\
\hline St Dev & 5.72 & 0.47 & 6.02 & 93.2 & 12.42 & 34.06 & 32.75 \\
\hline between & 5.48 & 0.13 & 5.78 & 87.02 & 8.29 & 31.46 & 30.24 \\
\hline within & 2.01 & 0.45 & 2.61 & 39.85 & 9.56 & 12.21 & 11.73 \\
\hline corr with GDP growth & -0.13 & -0.14 & 0.19 & -0.11 & -0.12 & -0.03 & -0.03 \\
\hline corr with Primacy & -0.29 & -0.16 & -0.23 & -0.45 & -0.44 & -0.21 & -0.20 \\
\hline \multicolumn{8}{|c|}{ EIB signed investments in projects linked to infrastructure (\% of GDP). 5 year average } \\
\hline Mean (countries) & $4.94(15)$ & $0.75(6)$ & $7.9(9)$ & $11.98(15)$ & $17.96(11)$ & $3.85(174)$ & $3.94(189)$ \\
\hline St Dev & 7.08 & 3.53 & 7.47 & 11.68 & 12.85 & 9.23 & 9.08 \\
\hline between & 5.91 & 1.48 & 6.25 & 10.47 & 7.45 & 7.23 & 7.13 \\
\hline within & 4.1 & 3.26 & 4.61 & 5.79 & 10.7 & 5.66 & 5.55 \\
\hline corr with GDP growth & -0.17 & -0.06 & 0.00 & 0.08 & -0.32 & 0.00 & 0.00 \\
\hline corr with Primacy & -0.28 & -0.02 & -0.24 & 0.56 & -0.37 & -0.09 & -0.10 \\
\hline \multicolumn{8}{|c|}{ EIB signed investments in other projects (\% of GDP). 5 year average } \\
\hline Mean (countries) & $6(15)$ & $0.42(6)$ & $9.93(9)$ & $8.85(15)$ & $10.96(11)$ & $4.51(174)$ & $4.62(189)$ \\
\hline St Dev & 8.71 & 2.55 & 9.36 & 5.14 & 8.72 & 8.46 & 8.49 \\
\hline between & 7.06 & 0.55 & 7.03 & 4.39 & 4.56 & 6.07 & 6.14 \\
\hline within & 5.34 & 2.5 & 6.66 & 2.9 & 7.55 & 5.91 & 5.87 \\
\hline corr with GDP growth & -0.12 & -0.03 & 0.15 & -0.03 & -0.25 & -0.03 & -0.03 \\
\hline corr with Primacy & -0.33 & 0.00 & -0.32 & 0.45 & 0.03 & 0.04 & 0.01 \\
\hline \multicolumn{8}{|c|}{ EIB signed investments in projects linked to infrastructure over total population. 5 year average } \\
\hline Mean (countries) & $14.71(15)$ & $0.85(6)$ & $24.49(9)$ & $374.47(15)$ & $182.28(11)$ & $52.03(171)$ & $49.06(186)$ \\
\hline St Dev & 25.11 & 3.53 & 28.93 & 309.78 & 177.38 & 154.1 & 148.35 \\
\hline between & 20.88 & 1.39 & 23.15 & 251.35 & 128.71 & 136.75 & 131.6 \\
\hline within & 14.59 & 3.29 & 18.89 & 191.72 & 127.73 & 69.48 & 66.78 \\
\hline corr with GDP growth & -0.15 & -0.07 & 0.00 & 0.08 & -0.30 & -0.02 & -0.02 \\
\hline corr with Primacy & -0.04 & -0.07 & 0.13 & 0.32 & -0.23 & -0.14 & -0.13 \\
\hline
\end{tabular}




\begin{tabular}{|c|c|c|c|c|c|c|c|}
\hline & ENP & $\begin{array}{l}\text { ENP } \\
\text { East }\end{array}$ & $\begin{array}{c}\text { ENP } \\
\text { South }\end{array}$ & EU 15 & EU 2004 & ROW & $\begin{array}{c}\text { Whole } \\
\text { Sample }\end{array}$ \\
\hline \multicolumn{8}{|c|}{ EIB signed investments in other projects over total population. 5 year average } \\
\hline Mean (countries) & $15.55(15)$ & $0.61(6)$ & $26.09(9)$ & $286.91(15)$ & $121.5(11)$ & $45.73(171)$ & $43.33(186)$ \\
\hline St Dev & 25.64 & 3.44 & 29.08 & 154.14 & 133.67 & 122.52 & 118.05 \\
\hline between & 20.51 & 0.73 & 21.67 & 101.46 & 77.76 & 102.72 & 98.97 \\
\hline within & 15.95 & 3.38 & 20.67 & 118.8 & 111.09 & 65.92 & 63.4 \\
\hline corr with GDP growth & -0.07 & -0.04 & 0.22 & -0.05 & -0.28 & -0.04 & -0.05 \\
\hline corr with Primacy & -0.19 & 0.00 & -0.11 & 0.20 & 0.03 & -0.09 & -0.08 \\
\hline \multicolumn{8}{|c|}{ EIB signed investments in projects linked to infrastructure over urban population. 5 year average } \\
\hline Mean (countries) & $21.05(15)$ & $1.7(6)$ & $34.71(9)$ & $513.67(15)$ & $286.53(11)$ & $77.58(171)$ & $73.08(186)$ \\
\hline St Dev & 32.95 & 7.47 & 36.94 & 435.69 & 301.02 & 220.47 & 212.26 \\
\hline between & 27.87 & 3.03 & 30.2 & 362.85 & 230.03 & 195.41 & 188.09 \\
\hline within & 18.51 & 6.93 & 23.51 & 257.74 & 205.51 & 99.93 & 96.01 \\
\hline corr with GDP growth & -0.15 & -0.06 & 0.02 & 0.09 & -0.26 & -0.02 & -0.02 \\
\hline corr with Primacy & -0.14 & -0.03 & -0.02 & 0.48 & -0.23 & -0.11 & -0.10 \\
\hline \multicolumn{8}{|c|}{ EIB signed investments in other projects over urban population. 5 year average } \\
\hline Mean (countries) & $23.64(15)$ & $1.15(6)$ & $39.52(9)$ & $396.7(15)$ & $184.06(11)$ & $73.12(171)$ & $69.18(186)$ \\
\hline St Dev & 37.15 & 6.77 & 41.43 & 227.4 & 215.03 & 173.05 & 166.89 \\
\hline between & 30.05 & 1.44 & 31.18 & 174.3 & 121.32 & 144.08 & 139.01 \\
\hline within & 22.73 & 6.64 & 29.21 & 152.43 & 181.06 & 95.11 & 91.46 \\
\hline corr with GDP growth & -0.09 & -0.03 & 0.21 & 0.00 & -0.26 & -0.04 & -0.04 \\
\hline corr with Primacy & -0.26 & 0.01 & -0.22 & 0.38 & -0.01 & -0.05 & -0.04 \\
\hline
\end{tabular}


Supplementary material B: Extended results equation (1)

\begin{tabular}{|c|c|c|c|c|c|c|c|}
\hline $\begin{array}{l}\text { Est. technique: } \\
\text { Dependent variable: }\end{array}$ & $\begin{array}{l}\text { (1) World } \\
\text { FE } \\
\text { growth }\end{array}$ & $\begin{array}{l}\text { (2) World } \\
\text { FE } \\
\text { growth }\end{array}$ & $\begin{array}{c}\text { (3) ENPs } \\
\text { FE } \\
\text { growth }\end{array}$ & $\begin{array}{c}\text { (4) ENPs } \\
\text { FE } \\
\text { growth }\end{array}$ & $\begin{array}{c}\text { (5) ENPs } \\
\text { FE } \\
\text { growth }\end{array}$ & $\begin{array}{c}\text { (6) ENPs } \\
\text { FE } \\
\text { growth }\end{array}$ & $\begin{array}{c}\text { (7) ENPs } \\
\text { IV-GMM } \\
\text { growth }\end{array}$ \\
\hline$\Delta \mathrm{UC}$ & $\begin{array}{c}0.1425^{* *} \\
(0.0592)\end{array}$ & $\begin{array}{c}-0.1408 * * \\
(0.0567)\end{array}$ & $\begin{array}{c}-0.8595 * * \\
(0.3602)\end{array}$ & $\begin{array}{c}-1.9378 * * * \\
(0.4906)\end{array}$ & $\begin{array}{c}-41.6551 * * \\
(16.7525)\end{array}$ & $\begin{array}{c}-64.9839 * * * \\
(20.9612)\end{array}$ & $\begin{array}{c}-1.7532 * * \\
(0.6694)\end{array}$ \\
\hline$\Delta \mathrm{UC} * \operatorname{Infr}$ & & & & & $\begin{array}{c}13.0160 * * \\
(5.1183)\end{array}$ & $\begin{array}{c}19.4401 * * \\
(6.6170)\end{array}$ & $\begin{array}{c}0.5268 * * \\
(0.2118)\end{array}$ \\
\hline Infr & & & & & $\begin{array}{c}46.0707 * * * \\
(12.7180)\end{array}$ & $\begin{array}{c}24.7167 \\
(27.6503)\end{array}$ & $\begin{array}{c}0.7978 \\
(0.9149)\end{array}$ \\
\hline UC & $\begin{array}{l}-0.1587 * \\
(0.0956)\end{array}$ & $\begin{array}{l}-0.5973 \\
(0.7178)\end{array}$ & $\begin{array}{l}-0.9755^{*} \\
(0.4753)\end{array}$ & $\begin{array}{l}-3.8497 \\
(4.1852)\end{array}$ & $\begin{array}{c}-3.1917 * * \\
(0.0670)\end{array}$ & $\begin{array}{l}-1.1473 \\
(6.1386)\end{array}$ & $\begin{array}{l}-0.0495 \\
(0.1983)\end{array}$ \\
\hline $\mathrm{UC} * \log (\mathrm{GDP} p \mathrm{c})$ & & $\begin{array}{c}0.2036 \\
(0.1865)\end{array}$ & & $\begin{array}{c}0.7662 \\
(1.0707)\end{array}$ & & $\begin{array}{l}-0.7359 \\
(1.7570)\end{array}$ & $\begin{array}{l}-0.0163 \\
(0.0437)\end{array}$ \\
\hline $\mathrm{UC}^{*} \log (\mathrm{GDP} \mathrm{pc})^{\wedge} 2$ & & $\begin{array}{c}-0.016 \\
(0.0121)\end{array}$ & & $\begin{array}{l}-0.0483 \\
(0.0801)\end{array}$ & & $\begin{array}{c}0.0515 \\
(0.1226)\end{array}$ & $\begin{array}{c}0.0012 \\
(0.0039)\end{array}$ \\
\hline $\log (\mathrm{GDP} p \mathrm{c})$ & & $\begin{array}{c}-8.7143 * * * \\
(1.6958)\end{array}$ & & $\begin{array}{l}-10.7150 \\
(10.6150)\end{array}$ & & $\begin{array}{l}-11.0758 \\
(9.4660)\end{array}$ & $\begin{array}{l}-0.6799^{*} \\
(0.3155)\end{array}$ \\
\hline Investment & & $\begin{array}{c}0.1066 * * * \\
(0.0336)\end{array}$ & & $\begin{array}{l}0.2584 * \\
(0.1457)\end{array}$ & & $\begin{array}{c}0.4272 * * * \\
(0.1027)\end{array}$ & $\begin{array}{c}0.0105 * * \\
(0.0033)\end{array}$ \\
\hline Pop_g & & $\begin{array}{c}-0.9103 * * * \\
(0.0231)\end{array}$ & & $\begin{array}{c}-2.1123 * * * \\
(0.4501)\end{array}$ & & $\begin{array}{c}0.6167 \\
(4.5031)\end{array}$ & $\begin{array}{c}0.0128 \\
(0.1456)\end{array}$ \\
\hline Country Fixed Effects & YES & YES & YES & YES & YES & YES & \\
\hline Year Fixed Effects & YES & YES & YES & YES & YES & YES & YES \\
\hline R-sq (within) & 0.160 & 0.421 & 0.359 & 0.568 & 0.605 & 0.865 & \\
\hline $\begin{array}{l}\text { Obs. (countries) } \\
\text { Hansen test p-value }\end{array}$ & 717 (183) & $671(173)$ & $58(15)$ & $58(15)$ & $32(13)$ & $32(13)$ & $\begin{array}{c}19(10) \\
0.982\end{array}$ \\
\hline
\end{tabular}

